\title{
Isolation and Identification of Bacillus Species from Soil for Phosphate, Potassium Solubilisation and Amylase Production
}

\author{
Shambhavi ${ }^{1}$, Ravindra Kumar ${ }^{1 *}$, Akash Tomar ${ }^{1}$, Purushottam ${ }^{1}$, \\ Jitender Singh ${ }^{1}$ and Shishu Pal Singh ${ }^{2}$
}

\author{
${ }^{1}$ College of Biotechnology, Sardar Vallabhbhai Patel University of Agriculture and \\ Technology, Meerut, Uttar Pradesh, India-250110 \\ ${ }^{2}$ College of Agriculture, Sardar Vallabhbhai Patel University of Agriculture and Technology, \\ Meerut, Uttar Pradesh, India-250110
}

*Corresponding author

\section{A B S T R A C T}

\begin{tabular}{|c|}
\hline $\begin{array}{l}\text { Key w o r d s } \\
\text { solubilisation, } \\
\text { nitrogen } \\
\text { fixation, PGPR, } \\
\text { Bacillus sp. and } \\
\text { Pseudomonas sp }\end{array}$ \\
\hline Article Info \\
\hline $\begin{array}{l}\text { Accepted: } \\
05 \text { April } 2020 \\
\text { Available Online: } \\
10 \text { May } 2020\end{array}$ \\
\hline
\end{tabular}

In the present study ten different Bacillus isolates were isolated from various soil samples and their identification was performed on the basis of Gram staining, colony morphology and biochemical tests. Gram positive rod shaped bacteria showing large, circular, opaque colonies having white or greyish white appearance were preserved on Nutrient agar slants for further identification. All isolates showed positive results for Catalase, Urease, Oxidase and motility biochemical tests. For other biochemical tests such as Citrate utilization, Vogues Proskauer, Nitrate reduction, Triple sugar iron Agar test, mixed results were obtained. Phosphate solubilisation and Potassium solubilisation activities of different isolates was performed. Out of ten isolates, none of the isolates solubilised phosphate on Pikovskaya's agar medium at $30^{\circ} \mathrm{C}$ after 15 days of incubation. Potassium solubilising activity was shown by two isolates (Sample code 3 and 9) out of ten. Among these two isolates, Sample code 3 showed highest potassium solubilisation and the clear zone on Aleksandrov agar medium was $9 \mathrm{~mm}$ and that of Sample Code 9 was $5 \mathrm{~mm}$, after 10 days of incubation at $30^{\circ} \mathrm{C}$. Further, the isolates were screened for the production of amylase and its assay has been performed. Seven isolates displayed zone of clearance in starch hydrolysis test except Sample code 5, 7 and 8. Sample code 5, 7 and 8 isolates gave negative results for TSI test also. The isolates were subjected to amylase activity test. Maximum amylase was produced by Sample code 9 at $3.90 \mathrm{mg} / \mathrm{ml}$ after 24 hours of incubation. Sample code 10 showed least amylase production at $0.86 \mathrm{mg} / \mathrm{ml}$.

\section{Introduction}

The soil acts as a reservoir for millions of microorganisms, of which approximately more than $85 \%$ are beneficial for plant life. Thus soil is a resilient eco system and soil microorganisms provide precious life to soil ecosystems catering to plant growth.
Soil microorganisms play a vital role in the evolution of agriculturally useful soil conditions and in stimulating plant growth (Compant, 2005).

Soil bacteria having beneficial effect on plant health are commonly referred to plant growth promoting rhizobacteria (PGPR). 
PGPR promote plant growth directly and indirectly but the specific mechanisms involved have not all been well characterized (Glick, 1995). The rhizospheric soil is dominated by the diverse bacterial communities (Buee et al., 2009; Farina et al., 2012; Bouizgarne et al., 2014; Mirza et al., 2014; Tahir et al., 2015). Bacillus species are considered to be the safe microorganisms that hold remarkable abilities for synthesizing a vast array of beneficial substances (Stein, 2005). Bacillus species have potent plant growth promoting traits such as IAA production, phosphate solubilisation, nitrogen fixation and bio control attributes like production of $\mathrm{HCN}$, siderophore, hydrolytic enzymes and antibiotics have been isolated from soybean (Senthilkumar et al., 2009). Bacillus species are Gram positive, endospore - forming, chemo heterotrophic rod shaped bacteria which are usually motile with peritrichous flagella; they are aerobic or facultative anaerobic and catalase positive (Waites et al., 2008). Among all PGPBs, Bacillus spp. has been reported to have tolerance towards the adverse conditions and, therefore, the most potential candidate used for enhancing the soil fertility and crop health (Vivas et al., 2003). Bacillus spp. is also known to enhance of macroand micronutrients in the soil and their uptake by host plant (Stefan et al., 2013).

There are several minerals containing essential elements in the soil, but most important minerals are nitrogen $(\mathrm{N})$, phosphorus $(\mathrm{P})$, and potassium $(\mathrm{K})$ (McAfee, 2008; White and Karley, 2010). Phosphorus is a major essential macro element required for plants to growth and development (Singh et al., 1994). Most of the essential plant nutrients, including phosphorus, remain in insoluble form in soil (Abd-Alla, 1994; Yadav et al., 1997). Chemical phosphate fertilizers are only meagrely soluble under the conditions in which they are applied to the soil. However, under such conditions microorganisms offer a biological rescue capability of solubilising the insoluble inorganic phosphorus of soil. Phosphate solubilising microorganisms (PSM) particularly those belonging to the genera Bacillus sp. and Pseudomonas sp. and many others possess the ability to bring insoluble phosphates in soil into soluble forms by secreting organic acids such as formic, acetic, propionic lactic, glycolic, fumaric and succinic acids (Rashid et al., 2004; Ivanova et al., 2006). Phosphate solubilising bacteria (PSB) mobilize insoluble inorganic phosphates from their surrounding soil mineral matrix to the bulk soil where they can be absorbed by plant roots for their growth and development (Pe'rez et al., 2007).

Potassium is the third important plant nutrient. Its plays a key role in the growth, metabolism, and development of plants. Without adequate supply of potassium, the plants will have poorly developed roots, grow slowly, produce small seeds and have lower yields (McAfee, 2008; White and Karley, 2010) and the increased susceptibility to diseases (Amtmann et al., 2008; Armengaud et al., 2010) and pest (Amtmann et al., 2006; Troufflard et al., 2010). A wide range of KSMs namely Bacillus mucilaginosus, Bacillus edaphicus, Bacillus circulans, Paenibacillus spp., Acidothiobacillus ferrooxidans, Pseudomonas, Burkholderia (Sheng et al., 2008; Lian et al., 2002; Rajawat et al., 2012; Liu et al., 2012; Basak and Biswas, 2012; Singh et al., 2010) have been reported to release potassium in accessible form from K-bearing minerals in soils.

Enzymes are protein molecules, which are necessary for life. Amylases are enzymes that break down complex carbohydrates. There are different sources to produce amylases. Plants, animals and microbes can produce amylases (Aiyer, 2004). 
Amylases are used in various biotechnological processes including renewable energy, pharmaceuticals, saccharification or liquefication of starch, detergents industries, warp sizing of textiles, fibers, paper industries, food staffs, baking, classification of haze formed in beer or fruit juices and for pre-treatment of animal feed to improve digestibility (Behal et al., 2006). Microorganisms produce different kinds of industrial enzymes. Because of their biochemical diversity and the ease with environmental and genetic manipulation, they have replaced enzymes, which traditionally have been isolated from complex eukaryotes (Pandey et al., 2000). Many microorganisms are able to produce amylases including Bacillus spp., Lactobacillus, Escherichia, Proteus, Strepotmyces sp., Pseudomonas sp. etc. For production of amylase for industrial use, isolation and characterization of new promising strains is a continuous process (Vaidya et al., 2015).

\section{Materials and Methods}

The present investigation was carried out to isolate native Bacillus isolates from different soil samples to carry out phosphate, potassium solubilisation and amylase production.

\section{Collection of samples}

Ten soil samples were collected from various fields, gardens of Sardar Vallabhbhai Patel University of Agriculture and Technology, Meerut and Bafawat village of Meerut district. Soil samples were collected in the sterile plastic pouches and brought to the laboratory under normal temperature for microbiological analysis.

\section{Isolation of Bacillus isolates}

Fifty gram soil samples were transferred to
$150 \mathrm{ml}$ sterile distilled water and heat treated at $\left(80^{\circ} \mathrm{C}\right)$ for 15 minutes. After that $0.1 \mathrm{ml}$ of soil suspension was spread over pre sterilized nutrient agar plates. The inoculated plates were incubated at $30^{\circ} \mathrm{C}$ for $24-48$ hours. The plates were examined after incubation period for rough and abundant colonies with waxy growth (1-4mm diameter) and irregular spreading edge. Suspected colonies were stained by Gram staining method. The Gram positive bacilli were maintained on Nutrient agar slants for additional identification tests (Kumar et al., 2012; Amin et al., 2015).

\section{Biochemical characterization}

The isolates were subjected to different biochemical parameters.

\section{Citrate utilization test}

Citrate Utilization test is used to detect the ability of an organism to utilize sodium citrate as a sole source of carbon and ammonium salt as a sole source of nitrogen. Simmon's citrate medium was prepared, sterilized and the slants were streaked back and forth with a light inoculum picked from the centre of a well-isolated colony. Test tubes were incubated aerobically at 35 to $37^{\circ} \mathrm{C}$ for up to 4-7 days. A colour change was observed from green to blue along the slant. (https://microbiologyinfo.com/citrateutilization-test-principle-media-procedureand-result/) (Claus, 1989 and Jawetz, E., et al., 1989)

\section{Vogues- proskauer test}

The test depends on the digestion of glucose to acetyl methyl carbinol (acetoin) MacFaddin, J.F.,(1980) (https://en.wikipedia.org/wiki/Voges\%E2\%80 \%93Proskauer_test). MR/VP broth was inoculated with a pure culture of the test organism. 
Test tubes were incubated for 24 hours at $35^{\circ} \mathrm{C}$. At the end of this time, $1 \mathrm{ml}$ of broth was transferred to clean test tube. Five percent alpha naphthol $(0.6 \mathrm{ml})$ followed by $0.2 \mathrm{~mL}$ of $40 \% \mathrm{KOH}$ was added to each test tube. Tubes were shaked gently to expose the medium to atmospheric oxygen and were allowed to remain undisturbed for 10 to 15 minutes. Change of colour was observed (https://microbeonline.com/voges-proskauertest-principle-procedure-results/).

\section{Motility test}

SIM medium was prepared, sterilized and poured in test tubes. Using an inoculating needle, the centre of SIM medium was stabbed to within the bottom half of the tube from pure 18-24 hour culture. Tubes were incubated at $33-37^{\circ} \mathrm{C}$ for $18-24$ hours.

This media has a very soft consistency that allows motile bacteria to migrate readily through them causing cloudiness in the stabbed area (Harley, 2005; MacFaddin 2000; Baron, E., and S. Finegold, 1990) (https://microbenotes.com/motility-testprinciple-procedure-and-results/).

\section{Catalase test}

Catalase is an enzyme, which is produced by microorganisms that live in oxygenated environments to neutralize toxic forms of oxygen metabolites; $\mathrm{H}_{2} \mathrm{O}_{2}$. A small amount of bacterial colony was transferred to a surface of clean, dry glass slide using a loop.

A drop of $3 \% \mathrm{H}_{2} \mathrm{O}_{2}$ (as given in appendix B3) was put on to the slide and mix. A positive result is the rapid evolution of oxygen (within 5-10 sec.) as evidenced by bubbling (Facklam and Elliott 1995)

(https://microbeonline.com/catalase-testprinciple-uses-procedure-results/).

\section{Nitrate reduction test}

Nitrate reduction test is used to detect the ability to produce nitrate reductase enzyme that hydrolyze nitrate $\left(\mathrm{NO}_{3}{ }^{-}\right)$to nitrite $\left(\mathrm{NO}_{2}^{-}\right)$. Nitrate broth was prepared, sterilized and inoculated with a heavy growth of test organism using aseptic technique.

Tubes were incubated at $37^{\circ} \mathrm{C}$ for 24 to 48 hours One $\mathrm{ml}$ of sulfanilic acid reagent and 45 drops of $\alpha$-naphthylamine was added to each test tube. Change of colour was observed (Conn and Breed, 1919). (https://microbeonline.com/nitrate-reductiontest-principle-procedure-results/).

\section{Triple sugar iron test}

Triple sugar iron agar test is used to determine whether microorganisms utilize glucose and lactose or sucrose fermentatively and produce $\mathrm{H}_{2} \mathrm{~S}$. Triple sugar iron medium was prepared, sterilized and slants were made. A well isolated colony was touched with a sterile stabbing loop.

TSI slants were inoculated by first stabbing through the centre of the medium to the bottom of the tube and then streak was done on the surface of the slant. Tubes were incubated at $35^{\circ} \mathrm{C}$ in for 18 to 24 hours. Reaction was observed (http://microbesinfo.com/2013/05/triplesugar-iron-agar-tsi-test/).

(Tille, 2014)

\section{Urease test}

Urease test is used to determine the ability of an organism to split urea, through the production of the enzyme urease. Urea broth was prepared, sterilized and poured into test tubes. Broth was inoculated with the inoculation loop containing loop full of organism. 
Incubate for $24-48$ hours at $37^{\circ} \mathrm{C}$. Change in colour was observed (Bailey, W. R., and E. G. Scott, 1974 and Christensen. 1946)(http://vlab.amrita.edu/?sub=3\&brch $=76$ \&sim=214\&cnt=2).

\section{Oxidase test}

The oxidase test is used to identify bacteria that produce cytochrome $\mathrm{c}$ oxidase, an enzyme of the bacterial electron transport chain (https://microbeonline.com/oxidasetest-principle-procedure-and-oxidasepositive-organisms/).

A strip of Whatman's No. 1 filter paper was soaked in a freshly prepared $1 \%$ solution of tertramethyl-p-phenylene-diamine

dihydrochloride. A strip was laid in a petri dish and moistened with distilled water. The colony to be tested was picked up and smeared over the moist area. A positive reaction was indicated by an intense deeppurple hue, appearing within 5-10 seconds (Isenberg, 2004; MacFaddin, 2000; Cowan and Steel, 1993)

\section{Analysis of phosphorus solubilising activity}

For Qualitative analysis isolates were spot inoculated at the centre of Pikovskaya's agar (Pikovskaya, 1948) plates aseptically. Plates were incubated at $37^{\circ} \mathrm{C}$ for 5-7 days. Diameter of clearance zone was measured.

\section{Analysis of potassium solubilising activity}

For Qualitative analysis isolates were spot inoculated at the centre of Aleksandrov agar (Hu et al., 2006) plates aseptically. Plates were incubated at $30^{\circ} \mathrm{C}$ for 7 days. Diameter of clearance zone was measured.

\section{Screening for amylase activity (starch hydrolysis test)}

Starch agar medium was prepared and poured into the Petri-plates (Shaw et al., 1995). After solidification of plates, bacterial colonies were streaked in straight lines on the plates with the help of sterilized inoculating loop.

Inoculated plates were incubated in inverted position at $30^{\circ} \mathrm{C}$ for $24-48$ hours. After incubation, bacterial colonies were visible on the plates and a clear zone was visible near the bacterial growth. The plates were flooded with Gram's iodine solution. No dark blue colour was seen around the bacterial colonies showing zone of degradation (Gupta et al., 2003).

\section{Amylase production}

Enzyme production medium (g/l) Starch $10.0 \mathrm{~g}$, Peptone 5.0g, Ammonium sulphate $2.0 \mathrm{~g}$, Potassium di hydrogen phosphate $1.0 \mathrm{~g}$, Di potassium hydrogen phosphate $2.0 \mathrm{~g}$, Magnesium sulphate $0.5 \mathrm{~g}$, Potassium chloride $0.5 \mathrm{~g}$ was prepared and sterilized. Twenty millilitre of medium was taken in a $100 \mathrm{ml}$ conical flask.

These flasks were inoculated with bacterial culture. Inoculated medium was incubated at $37^{\circ} \mathrm{C}$ in shaker incubator for $24 \mathrm{hr}$ at $120 \mathrm{rpm}$. At the end of fermentation period, the culture medium was centrifuged at 10,000 rpm for 15 min to obtain crude extract as supernatant, which served as enzyme source (Vaidya et al., 2015; Singh et al., 2016).

\section{Amylase assay}

One percent starch $(1 \mathrm{ml}), 2 \mathrm{ml}$ of $0.1 \mathrm{M}$ phosphate buffer ( $\mathrm{pH}$ 6.5) and $0.5 \mathrm{ml}$ of enzyme were incubated for $15 \mathrm{~min}$ at room temperature. One $\mathrm{ml}$ of DNS reagent was added and the solution was kept in boiling water bath for $10 \mathrm{~min}$. Solution was diluted by adding $8 \mathrm{ml}$ of distilled water (Bernfeld, 1955). 
The absorbance was measured at $540 \mathrm{~nm}$ against blank prepared as above without enzyme and incubation. One unit of $\alpha$ amylase activity was defined as the amount of enzyme that liberates $1 \mu$ mole of reducing sugars (maltose equivalents) per minute under the assay conditions (Miller, 1959).

\section{Standard graph for maltose}

Standard maltose solution $(10 \mathrm{mg} / \mathrm{ml})$ solution was prepared. Five separate test tubes were taken and 0.2, 0.4, 0.6, 0.8 and $1 \mathrm{ml}$ standard maltose solution was pipette out. A test tube containing blank solution was also prepared. The volume was maintained up to $2 \mathrm{ml}$ in each test tube including blank with distilled water. One ml DNS reagent was added to each test tube and test tubes were covered with aluminium foil. The test tubes were kept on boiling water bath for 5 minutes at $37^{\circ} \mathrm{C}$. The test tubes were allowed to cool and $9 \mathrm{ml}$ distilled water was added to each test tube and mixed well. Intensity of dark yellowish orange colour was measured as absorbance or OD in a spectrophotometer at $540 \mathrm{~nm}$. A graph was plotted with the concentration of maltose on $\mathrm{X}$ axis Vs OD at $540 \mathrm{~nm}$ on Y axis (http://vlab.amrita.edu/?sub=3\&brch=64\&sim $=163 \& \mathrm{cnt}=2$ ).

\section{Results and Discussion}

Bacillus isolated from ten different soil samples, were opaque, moist, white or greyish white in colour. The colony elevation appeared to be flat. The colony morphology study showed that the colony on nutrient agar medium formed circular or irregular edges. The colonies were of different sizes, some small, some medium and some large colonies were found. The results for various isolates have been summarized in Table I. After Gram staining and microscopy, it was observed that all Bacillus isolates were Gram positive as purple colour rods were observed at $40 \mathrm{X}$.
The rods were of different sizes. Sample code 2, 3, 4, 6 appeared to be small rods, Sample code 1 and 10 were medium rods and Sample code 5, 7, 8, 9 were large rods. Kannahi et al., (2015) used serial dilution and plating method for the isolation of bacterial colonies. These colonies were identified by gram staining and biochemical test. Bacteria belonging to the genera Bacillus, Pseudomonas, Serratia, Enterobacter, etc., are reported to solubilise the insoluble phosphatic compounds and aid in plant growth.

Biochemical analysis revealed that the all ten isolates showed positives results for Catalase, Motility, Urease and Oxidase tests. For other biochemical tests, mixed results were found, some being positive and some negative (Table II).

Out of 10 isolates, none of the isolates solubilised phosphate on Pikovskaya's agar medium, hence showed negative results. However, Kumar et al., (2012) found that a spore forming Bacillus sp. BPR7 strain was the best solubilizer of inorganic phosphates due to the production of organic acids. Similar results were obtained by Tripti et al., (2012) that an isolated bacterial strain $S_{2}$ (Bacillus sp.) was significant phosphate solubilizer. Karpagam et al., (2014) observed that isolate psm2 (Bacillus sp.) (0.786 U/ml) showed highest percent $\mathrm{P}$ solubilisation when compared to other isolates.

Two isolates namely 3 and 9 solubilised potassium on Aleksandrov agar medium. Potassium solubilising activities of these 2 isolates is shown in Table III. Rest of the isolates showed negative result. Similar study was carried out by Anjanadevi et al., (2015) in which 36 different bacteria were isolated from rocks of a major hill station at Ponmudi in Thiruvananthapuram, Kerala, India. A comprehensive characterization of $\mathrm{K}$ solubilisation from feldspar was achieved 
with these isolates which indicated that the $\mathrm{K}$ solubilising efficiency increases with decrease in $\mathrm{pH}$ and increase in viscosity and viable cell count. Based on the level of $\mathrm{K}$ solubilisation, two potent isolates were selected and identified as Bacillus subtilis ANctcri3 and Bacillus megaterium ANctcri7. The Bacillus isolates were also screened for amylase activity on Starch hydrolysis test. Out of ten isolates, seven bacteria showed the zone of clearance on starch agar media except 5, 7 and 8. After amylase production it was observed that Sample code 9 produced 3.90 $\mathrm{mg} / \mathrm{ml}$ of amylase. Similar study was performed by Singh et al., (2016) in which
Out of ten isolates, five bacteria showed zone of clearance on starch agar media and among five, Bacillus sp. B3 showed the maximum zone of clearance on the starch agar medium i.e. $8 \mathrm{~mm}$. So, B3 isolate was selected for the further study of amylase activity.

Isolated Bacillus sp. B3 was found to be effective in releasing high amount of reducing sugars. The amylase activity decreases from 0.981 to $0.215 \mathrm{U} / \mathrm{ml}$ as the incubation time increase from 24 to 72 hours at $35 \pm 2{ }^{\circ} \mathrm{C}$. Vaidya et al., (2015) isolated $\alpha$-amylase producing bacterial strains from the soil of potato dump sites.

Table.1 Bacillus isolates with different Characteristics on Nutrient agar medium

\begin{tabular}{|c|c|c|c|c|c|c|c|c|c|c|c|}
\hline & \multicolumn{9}{|c|}{ Sample code } \\
\hline $\begin{array}{c}\text { Characterist } \\
\text { ics }\end{array}$ & $\mathbf{1}$ & $\mathbf{2}$ & $\mathbf{3}$ & $\mathbf{4}$ & $\mathbf{5}$ & $\mathbf{6}$ & $\mathbf{7}$ & $\mathbf{8}$ & $\mathbf{9}$ & $\mathbf{1 0}$ \\
\hline Form & Circular & Circular & Irregular & Irregular & Circular & Circular & Circular & Circular & Circular & Circular \\
\hline Elevation & Flat & Flat & Flat & Flat & Flat & Flat & Flat & Flat & Flat & Flat \\
\hline Size & Medium & Large & Large & Large & Large & Medium & Medium & Medium & Medium & Small \\
\hline Opacity & Opaque & Opaque & Opaque & Opaque & Opaque & Opaque & Opaque & Opaque & Opaque & Opaque \\
\hline Colour & White & White & White & White & $\begin{array}{c}\text { Greyish } \\
\text { White }\end{array}$ & $\begin{array}{c}\text { Greyish } \\
\text { White }\end{array}$ & White & $\begin{array}{c}\text { Greyish } \\
\text { White }\end{array}$ & White & $\begin{array}{c}\text { Greyish } \\
\text { white }\end{array}$ \\
\hline Surface & Moist & Moist & Moist & Moist & Moist & Moist & Moist & Moist & Moist & Moist \\
\hline
\end{tabular}

Table.2 Biochemical characteristics of different Bacillus isolates studied in the present study

\begin{tabular}{|c|c|c|c|c|c|c|c|c|c|c|}
\hline \multirow{2}{*}{ Biochemical Tests } & \multicolumn{9}{|c|}{ Isolates } \\
\cline { 2 - 12 } & $\mathbf{1}$ & $\mathbf{2}$ & $\mathbf{3}$ & $\mathbf{4}$ & $\mathbf{5}$ & $\mathbf{6}$ & $\mathbf{7}$ & $\mathbf{8}$ & $\mathbf{9}$ & $\mathbf{1 0}$ \\
\hline Citrate utilization & + & - & + & + & + & + & + & - & + & + \\
\hline Vogues Proskauer & + & + & - & - & + & + & - & + & - & + \\
\hline Motility & + & + & + & + & + & + & + & + & + & + \\
\hline Catalase & + & + & + & + & + & + & + & + & + & + \\
\hline Nitrate reduction & - & - & - & - & + & + & + & + & + & + \\
\hline TSI & + & + & + & + & - & + & - & - & + & + \\
\hline Urease & + & + & + & + & + & + & + & + & + & + \\
\hline Oxidase & + & + & + & + & + & + & + & + & + & + \\
\hline
\end{tabular}


Table.3 Potassium solubilising activities of different Bacillus isolates

\begin{tabular}{|c|c|c|c|c|c|c|}
\hline Sample code & \multicolumn{3}{|c|}{ After 7 days } & \multicolumn{3}{c|}{ After 10 days } \\
\hline & $\begin{array}{c}\text { Colony } \\
\text { measurement } \\
\text { (d) (in mm) }\end{array}$ & $\begin{array}{c}\text { Zone } \\
\text { measurement } \\
\text { (D) (in mm) }\end{array}$ & (D-d) & $\begin{array}{c}\text { Colony } \\
\text { measurement } \\
\text { (d) (in mm) }\end{array}$ & $\begin{array}{c}\text { Zone } \\
\text { measurement } \\
\text { (D) (in mm) }\end{array}$ & (D -d) \\
\hline 3 & 11 & 19 & 8 & 11 & 20 & 9 \\
\hline 9 & 7 & 11 & 4 & 7 & 12 & 5 \\
\hline
\end{tabular}

Table.4 Concentration of Amylase produced by different Bacillus isolates

\begin{tabular}{|c|c|}
\hline Sample Code & Concentration $\mathbf{( m g} / \mathbf{m l})$ \\
\hline $\mathbf{1}$ & 3.49 \\
\hline $\mathbf{2}$ & 2.68 \\
\hline $\mathbf{3}$ & 0.95 \\
\hline $\mathbf{4}$ & 2.44 \\
\hline $\mathbf{5}$ & 2.65 \\
\hline $\mathbf{6}$ & 1.62 \\
\hline $\mathbf{7}$ & 2.16 \\
\hline $\mathbf{8}$ & 1.90 \\
\hline $\mathbf{9}$ & 3.90 \\
\hline $\mathbf{1 0}$ & 0.86 \\
\hline
\end{tabular}

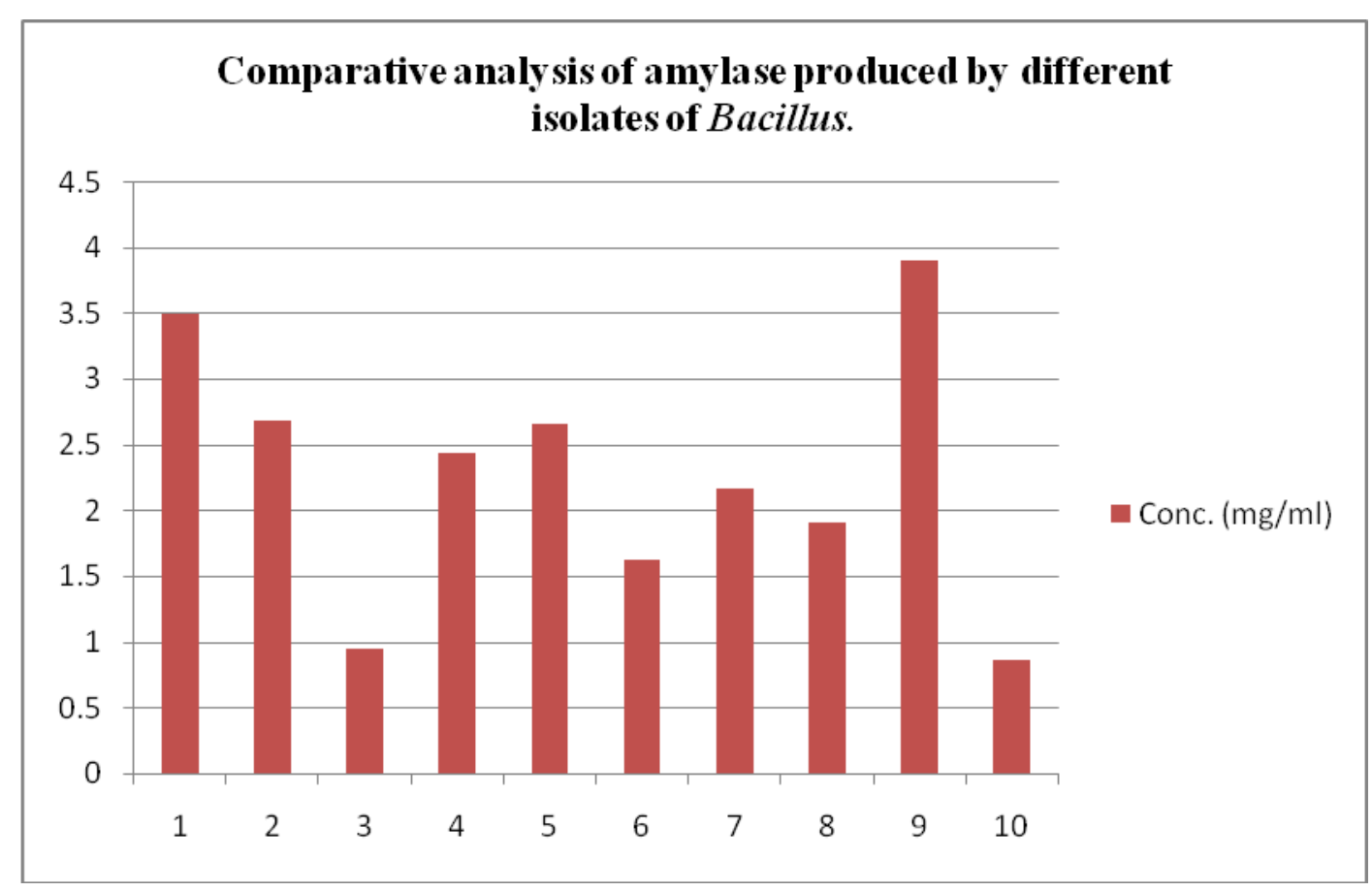

Figure.1 Comparison of amylase produced by different isolates of Bacillus on Enzyme production medium 
A total of 18 bacterial strains were isolated. Among which 5 strains gave zone of clearance with iodine solution on starch hydrolysis test. These were further selected and quantified. Amongst these, the isolate showing maximum absorbance was further optimized and characterized and found to belong to the genus Bacillus.

In this study, Comparative analysis of amylase produced by different isolates of Bacillus is shown in Figure I. Concentration of amylase produced by Bacillus isolates is given in Table IV.

This research was undertaken to isolate ten Bacillus isolates from different soil samples to test their ability to solubilise phosphate and potassium. Screening for the production of amylase and its assay has also been performed. Colonies of the Bacillus isolates appeared to be circular, flat, round and large on Nutrient agar plates. Few medium and small sized colonies were also observed. The length of the colonies varied from $1 \mathrm{~mm}$ to $12 \mathrm{~mm}$. Gram staining revealed that all isolates were Gram positive rods. However, the difference in the length of the rods was visible when microscopy was performed. After Biochemical analysis, it can be summarized that all Bacillus isolates showed positive results for Catalase, Urease, Oxidase and motility tests. For other biochemical tests differential results were obtained.

This also indicates that these were different isolates. Out of ten isolates none of the isolates were able to solubilise phosphate on Pikovskaya's agar medium even after 15 days of incubation at $37^{\circ} \mathrm{C}$. Two isolates (Sample code $3 \& 9$ ) out of ten solubilised Potassium on Aleksandrov agar medium. After 10 days of incubation, the difference between zone of clearance and colony diameter was found to be $9 \mathrm{~mm}$ and that of Sample code 9 was found to be $5 \mathrm{~mm}$.
Out of ten, seven isolates showed visible clear zone when streaked on starch agar plates after 24-48 hours of incubation except sample code $5,7 \& 8$. Sample code $5,7 \& 8$ were the only isolates which gave negative results for TSI Test. The isolates were further analyzed for amylase production and its assay. The concentration of amylase produced was between $0.86 \mathrm{mg} / \mathrm{ml}-3.90 \mathrm{mg} / \mathrm{ml}$ for the various Bacillus isolates.

\section{References}

Abd-Alla, M.H. (1994). Phosphatases and the utilization of organic phosphorus by Rhizobium leguminosarum biovar viceae. Lett. Appl. Microbiol, 18: 294-296.

Aiyer, P.V. (2004). Effect of C: N ratio on alpha amylase production by Bacillus licheniformis SPT 27. Afr. J. Biotechnol, 3: 519-522.

Amin, M., Rakhisi, Z., Ahmady, A.Z. (2015). Isolation and Identification of Bacillus Species From Soil and Evaluation of Their Antibacterial Properties. Avicenna J Clin Microb Infec., 2(1): e23233.

Amtmann, A., Hammond, J.P, Armengaud, P., White, P.J. (2006). Nutrient sensing and signaling in plants: potassium and phosphorus. Adv Bot Res, 43: 209-257.

Amtmann, A., Troufflard, S., Armengaud, P. (2008). The effect of potassium nutrition on pest and disease resistance in plants. Physiol Plant, 133: 682-691.

Anjanadevi, I.P., John, N.S., John, K.S., Jeeva, M.L., Misra, R.S. (2015). Rock inhabiting potassium solubilising bacteria from Kerala, India: characterization and possibility in chemical $\mathrm{K}$ fertilizer substitution. https://doi.org/10.1002/jobm.201500139.

Armengaud, P., Breitling, R., Amtmann, A. (2010). Coronatine intensive 1 (COII) mediates transcriptional responses of Arabidopsis thaliana to external potassium supply. Mol Plant, 3(2): 390-405.

Bailey, W. R., and E. G. Scott. (1974) Diagnostic microbiology, 4th ed. Mosby, St. Louis, MO.

Baron, E., and S. Finegold. Bailey and Scott's 
diagnostic microbiology, 8th ed. The Mosby Company, St. Louis, MO.1990

Basak, B.B, Biswas, D.R. (2012). Modification of waste mica for alternative source of potassium: evaluation of potassium release in soil from waste mica treated with potassium solubilising bacteria (KSB). Germany: Lambert Academic Publishing, ISBN 978-3-659-29842-4.

Behal, A., Singh, J., Sharma, M.K., Puri, P., Batra, N. (2006). Studied thermostable amylase producing Bacillus sp. Int. j. agri. Boil., 8: 80-83.

Bernfeld, P. (1955). Amylase aand $\beta$, In Methods in Enzymology (Colowick SP, Kaplan NO, ed.), Academic Press Inc, New York. 1: 149-158.

Bouizgarne, B., Aouamar, A.A.B., Maheshwari, D.K (2014). Diversity of Plant Associated Actinobacteria, Bacterial Diversity in Sustainable Agriculture. Springer International Publishing, Switzerland, 4199.

Buee, M., De Boer, W., Martin, F., Overbeek, L.V., Jurkevitch, E. (2009). The rhizospherezoo: an overview of plantassociated communities of microorganisms, including phages, bacteria, archaea, and fungi, and of some of their structuring factors. Plant Soil, 321: 189-212.

Christensen, W. B. Urea decomposition as a means of differentiating Proteus and paracolon cultures from each other and from Salmonella and Shigella types. J. Bacteriol. 1946, 52:461-466.

Claus, G.W.: Understanding Microbes: A Laboratory Textbook for Microbiology. W.H. Freeman and Co.: New York) 1989.

Compant, S. (2005). App Env Microbiol, 71(9): 4951-4959.

Conn HJ, Breed RS. The Use of the NitrateReduction Test in Characterizing Bacteria. J Bacteriol. 1919;4(3):267-290.

Farina, R., Beneduzi, A., Ambrosini, A. (2012). Diversity of plant growth-promoting rhizobacteria communities associated with the stages of canola growth. Appl Soil Ecol., 55: 44-52.

Glick, B.R. (1995). The enhancement of plant growth by free living bacteria. Can J Microbiol, 41: 109-17.
Gupta, R., Gigras, P., Mohapatra, H., Goswami, V.K., Chauhan, B. (2003). Microbial $\alpha-$ amylases: a biotechnological perspective. Process Biochem., 38: 1599-1616.

Harley, J. P.Laboratory exercises in microbiology, 6th ed. McGraw Hill, New York, NY.2005.

http://microbesinfo.com/2013/05/triple-sugariron-agar-tsi-test/

http://vlab.amrita.edu/?sub=3\&brch=64\&sim=163 $\& \mathrm{cnt}=2$

http://vlab.amrita.edu/?sub=3\&brch=76\&sim $=214$ $\& \mathrm{cnt}=2$

https://en.wikipedia.org/wiki/Voges\%E2\%80\%93 Proskauer_test

https://microbenotes.com/motility-test-principleprocedure-and-results/

https://microbeonline.com/catalase-test-principleuses-procedure-results/

https://microbeonline.com/nitrate-reduction-testprinciple-procedure-results/

https://microbeonline.com/oxidase-test-principleprocedure-and-oxidase-positive-organisms/

https://microbeonline.com/voges-proskauer-testprinciple-procedure-results/

https://microbiologyinfo.com/citrate-utilizationtest-principle-media-procedure-and-result/

https://microbiologyinfo.com/oxidase-testprinciple-uses-procedure-types-resultinterpretation-examples-and-limitations/

$\mathrm{Hu}$, X., Chen, J., Guo, J. (2006). Two phosphateand potassium-solubilizing bacteria isolated from Tianmu Mountain, Zhejiang, China. World J. Microbiol. Biotechnol., 22: 983990.

Isenberg HD, editor. Clinical Microbiology Procedures Handbook. American Society for Microbiology; 2004. p. 3.3.2-3.3.2.13

Ivanova, R., Bojinova, D., Nedialkova, K. (2006). Rock phosphate solubilisation by soil bacteria. Journal of the University of Chemical Technology and Metallurgy, 41(3): 297-302.

J Phytol, 3: 13-18.

Jawetz, E., et al., Medical Microbiology, Eighteenth Edition. (Appleton and Lange: San Mateo) 1989.

Kannahi, M., Megala, R. (2015). Phosphate solubilising potentiality of Bacillus subtilis and Pseudomonas aeruginosa on Vigna unguiculata growth using agrowaste as a substrate. World journal of pharmacy and 
pharmaceutical sciences, 4(8): 1238-1244.

Karpagam, T., Nagalakshmi, P.K. (2014). Isolation and characterization of Phosphate Solubilising Microbes from Agricultural soil. Int.J.Curr.Microbiol.App.Sci, 3(3): 601-614.

Kumar, P., Dubey, R.C., Maheshwari, D.K (2012). Bacillus strains isolated from rhizosphere showed plant growth promoting and antagonistic activity against phytopathogens. Microbiol Res., 167: 493499.

Lian, B., Fu, P.Q., Mo, D.M., Liu, C.Q. (2002). A comprehensive review of the mechanism of potassium release by silicate bacteria. Acta Mineral Sinica, 22: 179.

Liu, D., Lian, B., Dong, H. (2012). Isolation of Paenibacillus sp. and assessment of its potential for enhancing mineral weathering. Geomicrobiol J, 29(5): 413-421.

MacFaddin JF, editor. Biochemical Tests for Identification of Medical Bacteria. 3rd ed. Philadelphia:Lippincott Williams and Wilkins; 2000. p. 363-7

MacFaddin, J. F. 1980. Biochemical Tests for Identification of Medical Bacteria, 2nd ed. Williams and Wilkins, Baltimore

MacFaddin, J. F. 2000. Biochemical tests for identification of medical bacteria, 3rd ed. Lippincott Williams \& Wilkins, Philadelphia, PA.

McAfee, J. (2008). Potassium, a key nutrient for plant growth. Department of Soil and Crop Sciences.

http://jimmcafee.tamu.edu/files/potassium.

Miller, G.L. (1959). Use of dinitrosalicylic acid reagent for determination of reducing sugar. Analytical Chemistry, 31(3): 426-428.

Mirza, M.S., Potisap, C., Nusslein, K., Bohannan, B.J., Rodrigues, J.L. (2014). Response of free-living nitrogen-fixing microorganisms to land use change in the Amazon rainforest. Appl Environ Microbiol, 80: 81288.

Pandey, A., Nigam, P., Soccol, C.R., Soccol, V.T., Singh, D., and Mohan, R. (2000). Advances in microbial amylases. Biotechnol. Appl. Biochem., 31: 135-152.

Pe'rez, E., Sulbara'n, M., Ball, M.M., Yarza'bal, L.A. (2007). Isolation and characterization of mineral phosphate-solubilising bacteria naturally colonizing a limonitic crust in the south-eastern Venezuelan region. Soil Biology \& Biochemistry, 39: 2905-2914.

Pikovskaya, R.I. (1948). Mobilization of phosphorus in soil in connection with the vital activity of some microbial species. Mikrobiologiya, 17: 362-370.

$\mathrm{R}$ Facklam and $\mathrm{J}$ A Elliott .Identification, classification, and clinical relevance of catalase-negative, gram-positive cocci ,excluding the streptococci and enterococci.Clin.Microbiol. Rev. 1995, 8(4):479

Rajawat, M.V.S., Singh, S., Singh, G., Saxena, A.K. (2012). Isolation and characterization of $\mathrm{K}$-solubilizing bacteria isolated from different rhizospheric soil. In: Proceeding of 53rd Annual Conference of Association of Microbiologists of India. p. 124.

Rashid, M., Samina, K., Najma, A., Sadia, A., and Farooq, L. (2004). Organic acids production and phosphate solubilization by phosphate solubilizing microorganisms under in vitro conditions. Pak. J. Biol. Sci., 7: 187-196.

Cowan; S. T., Steel, K.J. (1993). Cowan and Steel's Manual for the Identification of Medical Bacteria (3rd ed.). Cambridge: Cambridge University Press. ISBN 9780511527104.

Senthilkumar, M., Swarnlakshmi, K., Govindasamy, V., Lee, Y.K., Annapurna, K. (2009). Bio control potential of soybean bacterial endophytes against charcoal rot fungus Rhizoctonia bataticola. Curr Microbiol, 58: 288-93.

Shaw, J.F., Lin, F.P., Chen, S.C. and Chen, H.C. (1995). Purification and properties of an extracellular -amylase from Thermus sp. Botanical Bulletin of Academia Sinica, 36: 195-200.

Sheng, X.F., Zhao, F., He, H., Qiu, G., Chen, L. (2008). Isolation, characterization of silicate mineral solubilising Bacillus globisporus Q12 from the surface of weathered feldspar. CanJ Microbiol, 54: 1064-1068.

Singh, G., Biswas, D.R., Marwah, T.S. (2010). Mobilization of potassium from waste mica by plant growth promoting rhizobacteria and its assimilation by maize (Zea mays) 
and wheat (Triticum aestivum L.). J Plant Nutr, 33: 1236-1251.

Singh, P., Kumari, P. (2016). Isolation and characterization of amylase producing Bacillus spp. from selected soil sample. Int. J. Res. Biosciences, 5(2): 24-29.

Singh, S., and Kapoor, K.K. (1994). Solubilization of insoluble phosphates by bacteria isolated from different sources. Environ Ecol, 12: 51-55.

Stefan, M., Munteanu, N., Mihasan, M. (2013). Application of plant growth promoting rhizobacteria to runner bean increases seed carbohydrate and protein yield. Analele Stiintifice ale Universitatii“" Al. I. Cuza" Din Iasi. (SerieNoua). Sectiunea 2. a. Geneticasi Biologie Moleculara, 14: 29-36.

Stein, T. (2005). Bacillus subtilis antibiotics: structures, synthesis and specific functions. Mol Microbiol, 56(4): 845-57.

Tahir, M., Mirza, M.S., Hameed, S., Dimitrov, M.R., Smidt, H. (2015). Cultivation-based and molecular assessment of bacterial diversity in the rhizosheath of wheat under different crop rotations. PLOS ONE, 10: p. e0130030.

Tille P.M. 2014. Bailey and Scott's diagnostic microbiology. Thirteen edition. Mosby, Inc., an affiliate of Elsevier Inc. 3251 Riverport Lane. St. Louis. Missouri 63043

Tripti., Kumar, V., and Anshumali. (2012). Phosphate Solubilizing Activity of Some Bacterial Strains Isolated from Chemical Pesticide Exposed Agriculture Soil. International Journal of Engineering Research and Development, 3(9): 01-61.

Troufflard, S., Mullen, W., Larson, T.R., Graham, I.A., Crozier, A., Amtmann, A.,
Armengaud, P. (2010). Potassium deficiency induced the biosynthesis of oxylipins and glucosinolatesin Arabiodopsis thaliana. Plant Biol, 10(1): 172.

Vaidya, S., and Rathore, P. (2015). Isolation, screening and characterization of amylase producing bacteria from soil potato dump sites from different regions of Madhya Pradesh. https://www.researchgate.net/publication/2 77242517

Vivas, A., $\quad$ Marulanda, A., $\quad$ RuizLozano, J.M., Barea, J.M., Azcon, R. (2003). Influence of a Bacillus sp. on physiological activities of two arbuscular mycorrhizal fungi and on plant responses to PEG-induced drought stress. Mycorrhiza, 13: 249-256.

vlab.amrita.edu,. (2011). Construction of Maltose Standard Curve by DNS Method. Retrieved 2 November 2019, from vlab.amrita.edu/?sub=3\&brch $=64 \& \operatorname{sim}=16$ $3 \& \mathrm{cnt}=1$

Waites, M.J., Morgan, N.L., Rockey, J.S., Higton, G. (2008). Industrial Microbiology an Introduction. London: Blackwell Publisher

White, P.J, Karley, A.J. (2010). Potassium In: Cell biology of metals and nutrients, plant cell monographs. Berlin: Springer, 17: 199224.

Yadav, K.S. and Dadarwal, K.R. (1997). Phosphate solubilisation and mobilization through soil microorganisms. In: Biotechnological Approaches in Soil Microorganisms for Sustainable Crop Production. Scientific Publishers, Jodhpur, 293-308.

\section{How to cite this article:}

Shambhavi, Ravindra Kumar, Akash Tomar, Purushottam, Jitender Singh and Shishu Pal Singh. 2020. Isolation and Identification of Bacillus Species from Soil for Phosphate, Potassium Solubilisation and Amylase Production. Int.J.Curr.Microbiol.App.Sci. 9(05): 415426. doi: https://doi.org/10.20546/ijcmas.2020.905.046 